\title{
Recreational Value of the Pigeon Island National Park, Sri Lanka \\ I.G.N.S. Ilukdeniya ${ }^{1}$ and Krishnal Thirumarpan ${ }^{2}$
}

\section{Abstract}

Coastal resources are crucial and important to support life in the planet. Benefits derived from coastal resources are well known and widely recognized. Pigeon Island National Park is one of the best remaining coral reefs with high live coral cover in Sri Lanka and is an ideal location for scuba diving and snorkelling. The objective of this research was to explore the recreational value of the Pigeon Island. A sample of hundred participants including both foreigners and locals were selected using systematic sampling and every fifth person who passes the entry point was interviewed. Contingent valuation method was used in the analysis in the study. The result revealed that majority (92\%) of foreigners who visited the island were non- Asians. Almost all the foreign visitors participated in Scenic visit, diving visit, whale watching and Sunbath. Both locals and foreigners ranked diving as the most preferred activity. Average cost for boating was Rs. 1,300 per hour for foreign visitors, average cost for diving was Rs. 3470 per person per hour which were nearly twice the value that of local visitors. Foreign visitors' mean willingness to pay for diving was Rs.3670 and, for whale watching was Rs.1510. But for local visitor's willingness to pay for diving visit was Rs.1240, for whale watching was Rs.919.00. Average willingness to pay of the foreign visitors for entrance fee was Rs.1560 and the average willingness to pay of the local visitors for the entrance fee was Rs 644.00 .

Results of the $\mathrm{T}$ test presented that significant difference between foreign visitors and local visitors for total and entrance fee willingness to pay, hours of spending, costs for boating, for diving and for whale watching. Chi square analysis showed that there was a high significant association between the total willingness to pay by the local visitors and the education level of the respondent $\left(\mathrm{X}^{2}=76.75, \mathrm{p}<0.01\right)$. A significant association was observed between the total willingness to pay by the local visitors and the cost for boating in the Pigeon Island $\left(\mathrm{X}^{2}=36.52, \mathrm{p}<0.01\right)$. In addition, total willingness to pay was significantly affected by age, hours of spending, number of the group members and expenses for meals. The study revealed that the current entrance fees do not capture the economic value of the Pigeon Island.
${ }^{1,2}$ Department of Agricultural Economics, Faculty of Agriculture Eastern University, Sri Lanka

'skrish_16@yahoo.com

Keywords: Pigeon Island, Recreational value, Travel cost method, Willingness to pay 


\section{Original Article}

\section{INTRODUCTION}

Coastal resources are crucial and important to support life in the planet. Benefits obtained from coastal resources are well known and widely recognized. Coastal resources are sources of primary and secondary productions, and biodiversity. The importance of the coast in global material and energy cycles is now beginning to be better appreciated. Recent estimates of the economic value of the marketed and non-marketed ecosystem services of the coastal system indicate a large contribution to human welfare plus raw materials, recreational, and cultural services (Costanza et al., 1997).

Coastal resources refer to the natural resources found in coastal areas, which is useful for human beings, today or in the coming future, including land, forests, coastal waters and wetlands, sand minerals, hydrocarbons, and living coastal organisms (Walters, 1998; Jin et al, 2002). Coastal resources also generally include other important resources such as archaeological, historic, sacred, or gender-specific significance (Walters, 1998).Coastal zones throughout the world are attractive and important areas for socio-economic development. However, increasing number of human activities in coastal zones can have disastrous consequences on coastal resources (Jean, 2002).

Sri Lanka consists of a total land area at about $1,585 \mathrm{~km}$ of which $300 \mathrm{~km}$ are beaches and sand dunes. The coastal areas are generally low-lying, and landscapes exhibit considerable variety characterized by bays, lagoons, headlands, coastal marshes and dunes (United Nations Environment Programme, Annual Evaluation report, 2005). The areal extent of biologically productive mangroves systems, estuaries, coral reefs and sea grasses are decreasing due to natural and man-made causes. The development of the country has been closely related to maritime activities. In coastal region, over $80 \%$ of tourist hotels were located and two third of all industrial production of Sri Lanka is taken place (Bandara \& Ratnayake, 2015).

Tourism sector is becoming the most powerful growth engine in the millennium. Tourism involves travelling to relatively undisturbed or uncontaminated natural areas with the specific objects of studying, admiring and enjoying the scenery and its wild flora as well as other existing cultural and historical aspects. These include place of archaeological and historical importance, pilgrimage centers, sanctuaries, national parks, hill resorts and sea beaches (Jude et al., 2011).

Sri Lankan tourism industry is one of the fast emerging industries of the economy with average annual revenue of US \$ 500 million at present. It is the sixth largest foreign exchange earner in Sri Lanka. It has created employment for about 125,000 persons. At present, nearly half a 
million tourists visit the country every year. Sri Lanka has exotic sandy beaches, large greeneries, historical artifacts, and a good climate, spectacular landscape in the highlands, a rich biodiversity and friendly and welcoming people. These distinctive opportunities will be utilized to develop the tourism industry as a major growth sector in the development of the economy. In present Sri Lanka has achieved a high growth in tourism industry with the current political stability as well as the opening of the North and East to tourist. Today Sri Lanka tourism contributes enormously to the Sri Lankan economy. Because after the end of the civil war in 2009, Sri Lanka witnessed a strong upsurge in tourism. Trincomalee is one of major place attracted by both local and foreign visitors, which leads for higher earning to the tourism industry Sri Lanka.

The Eastern Province of Sri Lanka, comprising the three coastal districts of Trincomalee, Batticaloa, and Ampara covers a land area of 9,635 $\mathrm{km}^{2}$, has a coastline of approximately $360 \mathrm{~km}$ in length, and supports a population of approximately 1.42 million people, $78 \%$ of which are rural, and 30\% live within the coastal belt. The entire Eastern coast falls within the dry zone of Sri Lanka having a common climate (Kevin, 2007).

Trincomalee district with its natural deep water harbor at the sea port city of great Trincomalee bay, Nilaveli
Beach, Uppuveli Beach, Pigeon Island, off-shore whale watching and Dolphin watching, Kanniyai Hot Springs, Colonial Fort Fredrick and Koneshwara Hindu temple provides joy and experience to Sri Lanka holidays tourists. Swimming at Nilaveli and Uppaveli tropical beaches, snorkeling at Pigeon Island, enjoying marine life at offshore Whale watching and Dolphin watching and getting close to the nature with wild elephants at Somawathie Chaitiya Sanctuary was certainly bound to deepen the experiences among tourists.

National parks, wild life reserves and green spaces included in the classification of public recreational resources. Pigeon island national park is one of the marine national parks in Sri Lanka.Pigeon Island National Park consists of two small islands off the East coast, North of Trincomalee. The Island gets its name from Blue Rock Pigeon, a native exotic bird lives within rocks in these islands. In the year 1974, two islands were declared as a sanctuary under Fauna and Flora Protection Ordinance (FFPO) for protecting the nationally endangered wild rock pigeons (Columba livia), that colonize the rocky cliffs in large numbers (Perera and Kotagama, 2016). In 2003 this area was upgraded to the status of a National Park and the boundaries were extended to include coral reef around them (IUCN SL/CEA, 2006; IUCN, 2002). This Pigeon Island National Park has one of 
the best remaining coral reefs with high live coral cover in the country and is an ideal location for scuba diving and snorkeling (IUCN SL/CEA, 2006; IUCN, 2002). In addition to that, nature trail in the inland areas for ecotourism and constructed buildings under the colonial governments also contributes for the increase in the tourism attraction of the Pigeon Island. The hotels at the beaches of Trincomalee make arrangements on boat trips to the Pigeon Island for the tourists to enjoy in swimming and snorkeling in the shallow water. The shallow water around the island delight those who would like spear fishing. Many of the 100 species of corals and 300 coral reef fishes recorded around the Trincomalee area are found in the national park. Juvenile and adult Black-tip reef shark are seen around the shallow coral areas whilst, Hawksbill turtle, Green turtle and Olive Ridley are the visiting sea turtles of the coral reef.

Contingent valuation is widely used in most environmental valuation studies and is depended on every individual's stated willingness-to-pay for the hypothetical changes in environmental amenity (Walsh, 1986). The first contingent valuation survey was done by Davis (1963) to estimate the value to ecologists of a recreational area and compared the results with the travel cost approach and found the results were quite similar. Since then, many researches were done using contingent valuation method.

\section{Problem Statement}

There has been a multiplicity of recent valuation studies on coastal and ocean resources. However, coastal resource valuation is still a new field to Sri Lanka. So far, there were no studies related to the estimation of recreational value of the Pigeon Island, Sri Lanka.

The aim of this study was to estimate the recreation value of the Pigeon Island- Trincomalee, Sri Lanka. Specific Objectives were to identify socio economic status of tourists, to estimate the recreational value of the Pigeon Island and to identify the major limitations for recreation.

\section{RESEARCH METHODOLOGY}

\section{Study Area}

Trincomalee district is located in the East of Sri Lanka. The present research was conducted in the Pigeon Island in Kuchchaveli Divisional Secretariat Division (DS) of Trincomalee district. Kuchchaveli Divisional Secretary Division is the longest DS Division in Trincomalee District. It is situated in the Eastern costal area and bounded by Mullaitheevu district in North and Bay of Bengal in the East and Trincomalee Town and Gravets DS Division in the South and Morawewa and Gomarankadawala DS Division in the west. Distance between Trincomalee to Pigeon Island National Park was only about $19 \mathrm{~km}$. Fringed by a coral reef off Nilaveli in Trincomalee 


\section{Original Article}

is the Pigeon Island, one of the two marine national parks of Sri Lanka, situated $1 \mathrm{~km}$ off the coast of Nilaveli.

\section{Selection of sample}

The collection of primary data was geared towards visitors' experiences and socioeconomic characteristics. The questionnaire was designed to collect information on: (1) socioeconomic factors (2) on-site and off-site recreational behaviour; and (3) travel experiences and trip costs;

\section{Sampling}

In the survey, systematic sampling was employed. The study was done in 2017. Individual visitors were chosen as respondents for the interviews. Contingent valuation method is an indirect method used to estimate user benefits from visits to recreational sites (such as beaches, parks and heritage site) (Liston-Heyes and Heyes, 1999). Many studies in Asia have valued the recreational benefits of natural resources based on surveys of only domestic tourists. For example, the estimated tourism value of Cuc Phuong National Park (Francisco and Glover 1999) did not include the value from international tourists, even though the authors had interviewed foreigners. A study in Lumpinee Public Park in Thailand (Dixon and Hufschmidt 1986) also omitted foreigners. The reason for this omission in both cases was that the number of foreign tourists was too low to give a significant result - a problem that often arises in such studies. However, according to statistics from the Tourism Board of Sri Lanka, a considerable income is being earned by foreign tourists to Pigeon Island. Therefore, it would be unacceptable to exclude responses of foreign tourists from the calculation. In this research, values for Sri Lankans and foreign visitors were calculated separately and then added to derive the total recreational value of the Pigeon Island.

\section{Research questions}

The research was conducted in the form of a survey that addressed the following questions:

a) How factors such as income and visitors' socioeconomic characteristics affect the recreational demand for the Pigeon Island?

b) What is the composition of the recreational value of the Pigeon Islands, which includes values gleaned from foreign visitors as well as from Sri Lankan visitors?

c) What is the visitors' total willingness to pay for visiting the Pigeon Island, and what factors affect their willingness to pay?

Tourists perceive the value of parks in different ways due to their personal characteristics, such as age, education, gender, income, experience of using the parks. The data were collected using a survey. A total of 100 samples were collected: 50 from Local visitors and 50 from foreign visitors. Respondents were asked the activities 
done in the Pigeon Island and total Island visit. willingness to pay for the Pigeon

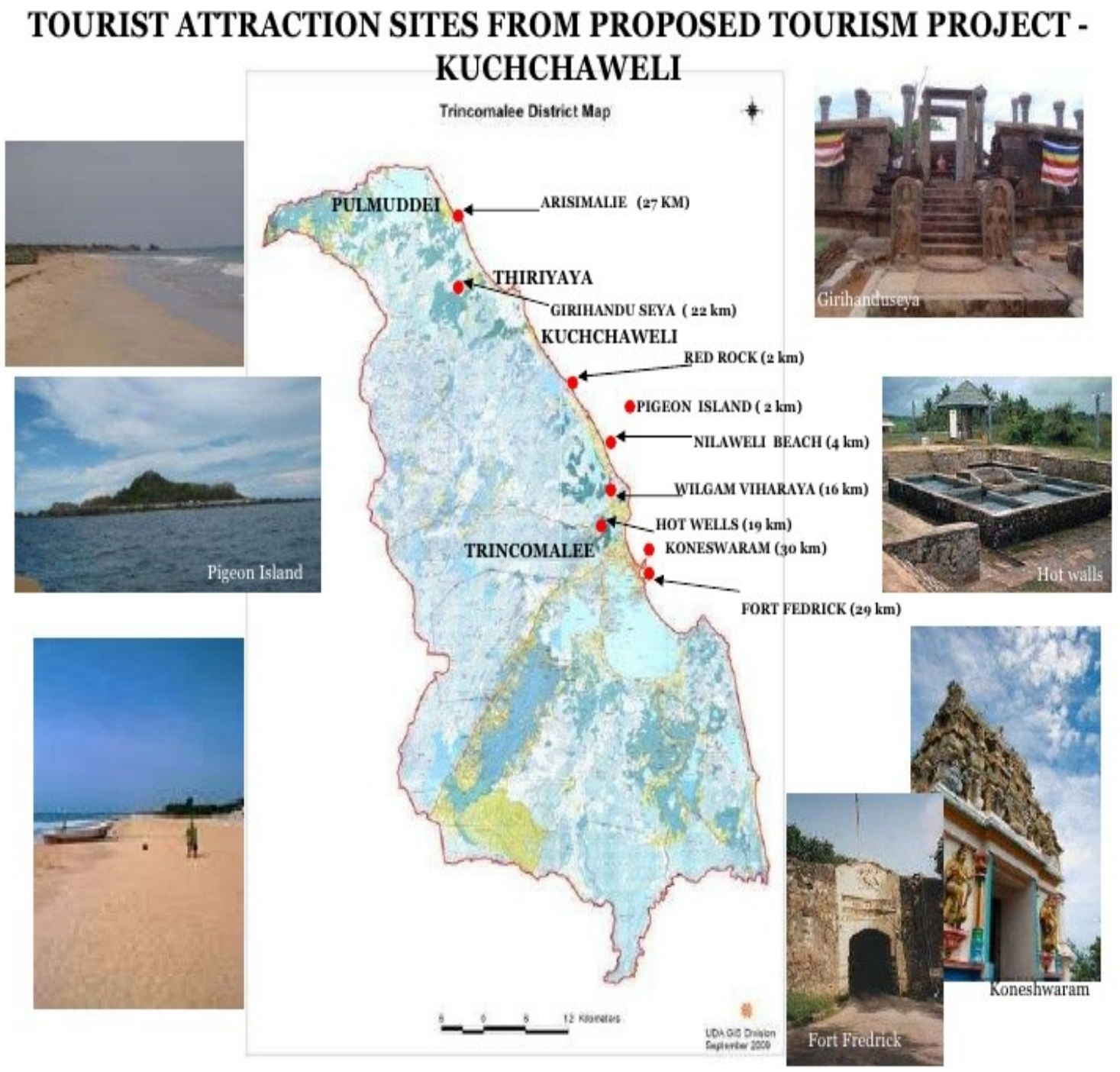

Figure 1: Tourist attraction sites in Kuchchaveli D. S. division

\section{Data Analysis}

Questionnaire had two major parts such as personal data and data related to the travel. There were two separate questionnaires used for Local visitor (Sri Lankan) and foreign visitors.

Descriptive statistics were done for questionnaires to explore the socio economic status of the visitors. Multiple regression analysis was done to explore the factors affecting travels of visitors on their total willingness to pay. Valuation on coastal resource which has characteristics as public goods can be done by non-market valuation technique. Willingness to Pay (WTP) concept was useful to measure the benefits by providing economic valuation of environmental goods. 


\section{Original Article}

\section{Model Specification}

In the model, WTP was endogenously determined and is a function of the following independent variables age, marital status, gender, hours of spending on the Pigeon Island visit, number of group members in the visit group and expenses for the meals.

$\log Y=\beta_{0}+\beta_{1} X_{1}+\beta_{2} X_{2}+\beta_{3} X_{3}+\beta_{4} X_{4}+$ $\beta_{5} X_{5}+\beta_{6} X_{6}$

Where,

$\mathrm{Y}=$ Total willingness to pay on the Pigeon Island visit (Rs),

$X_{1}=$ Age of the household head (Years)

$\mathrm{X}_{2}=$ Marital status

$\mathrm{X}_{3}=$ Gender

$\mathrm{X}_{4}=$ Hours of spending

$X_{5}=$ Number of group members in the visit $X_{6}=$ Expenses for the meals (Rs)

T- Test was used to find out the significant difference between foreign visitors and local visitors for their total willingness to pay on visit to the Pigeon Island, hours of spending in Pigeon Island, willingness to pay for entrance fee, cost for boating per hour, cost for diving visit and cost for whale watching.

Chi-square analysis was done to find out the association between different variables.

\section{RESULTS AND DISCUSSION}

Socio demographic and economic profile of the visitors

Table 1: Individual level information of local visitors

\begin{tabular}{|c|c|}
\hline $\begin{array}{l}\text { Individual } \\
\text { information }\end{array}$ & $\begin{array}{l}\text { Percentage } \\
\%\end{array}$ \\
\hline \multicolumn{2}{|l|}{ Gender } \\
\hline Male & 52 \\
\hline Female & 48 \\
\hline \multicolumn{2}{|l|}{ Employment status } \\
\hline Government employee & 36 \\
\hline Private employee & 48 \\
\hline Self-employee & 10 \\
\hline Student & 2 \\
\hline Unemployed & 4 \\
\hline \multicolumn{2}{|l|}{ Marital status } \\
\hline Single & 30 \\
\hline Married & 68 \\
\hline Divorced & 2 \\
\hline \multicolumn{2}{|l|}{ Education level } \\
\hline Secondary(Grade6-A/L) & 28 \\
\hline Tertiary (diploma/degree & 68 \\
\hline etc.) & 2 \\
\hline Others(vocational training) & 2 \\
\hline \multicolumn{2}{|l|}{ No schooling } \\
\hline \multicolumn{2}{|l|}{ Monthly income level(Rs) } \\
\hline $0-15000$ & 2 \\
\hline $15000-30000$ & 10 \\
\hline $30000-45000$ & 50 \\
\hline $45000-60000$ & 34 \\
\hline $60000-75000$ & 4 \\
\hline
\end{tabular}

Most (48\%) of the local visitors came to the Pigeon Island were employed in private companies. Very few of them were students $(2 \%)$.

$50 \%$ of the local visitors in the sample population were receiving a monthly income within the range of Rs.3000040000 . 


\section{Original Article}

Table 2: Districts from which the visitors came to the Pigeon Island

\begin{tabular}{ll}
\hline District & Percentage $\%$ \\
\hline Kandy & 12 \\
Matale & 8 \\
Nuwaraeliya & 4 \\
Anuradhapura & 4 \\
Polonnaruwa & 8 \\
Vavunia & 4 \\
Ampara & 2 \\
Batticaloa & 2 \\
Trincomalee & 8 \\
Kurunegala & 10 \\
Galle & 4 \\
Hambantota & 2 \\
Matara & 2 \\
Badulla & 6 \\
Monaragala & 2 \\
Kegalle & 4 \\
Ratnapura & 2 \\
Colombo & 2 \\
Gampaha & 10 \\
Kalutara & 4 \\
\hline
\end{tabular}

There were $12 \%$ of visitors from Kandy followed by $10 \%$ from Gampaha and Kurunegala.

\section{Individual level information of foreign} visitors

$42 \%$ of the foreign visitors were educated up to Bachelor's or equivalent level and $38 \%$ up to Master's or equivalent level. $74 \%$ of the foreign visitors were receiving monthly income in the range between US\$ 17500-20000 per month.

Table 3: Individual level information of foreign visitors

Individual level $\quad$ Percentage \%

\section{Gender}

Male

Female

Marital status

Single

Married

88

Education level

Bachelor's or equivalent 42

level

Master's or equivalent 20

level

Doctoral or equivalent

level

\begin{tabular}{|c|c|}
\hline $\begin{array}{l}\text { Monthly } \\
\text { level(US\$) }\end{array}$ & income \\
\hline $17500-20000$ & \\
\hline
\end{tabular}

Table 4: Native Countries of foreign visitors

\begin{tabular}{ll}
\hline Country & Percentage \% \\
\hline Australia & 8 \\
Argentina & 6 \\
Ireland & 2 \\
Netherland & 4 \\
Czech republic & 2 \\
Norway & 8 \\
Sweden & 4 \\
Spain & 4 \\
France & 4 \\
Finland & 4 \\
German & 10 \\
Chile & 2 \\
Belarus & 6 \\
Italy & 4 \\
Russia & 8 \\
Ukraine & 4 \\
Rumania & 4 \\
Belgium & 2 \\
Poland & 2 \\
Canada & 4 \\
New Zealand & 8 \\
\hline
\end{tabular}




\section{Original Article}

$10 \%$ of foreign visitors were from

German followed by $8 \%$ were Australians, Norwegians, Russians and New Zealand.

Table 5: Information source about the

\begin{tabular}{lll}
\multicolumn{3}{c}{ Pigeon Island } \\
\hline $\begin{array}{l}\text { Information } \\
\text { source }\end{array}$ & $\begin{array}{l}\text { Local } \\
\text { visitors } \\
\mathbf{( \% )}\end{array}$ & $\begin{array}{l}\text { Foreign } \\
\text { visitors } \\
\mathbf{( \% )}\end{array}$ \\
\hline Magazine & 00 & 00 \\
News paper & 00 & 00 \\
TV/Radio & 4 & 00 \\
Web site & 78 & 96 \\
Research Article/ & 00 & 00 \\
Journal & 98 & 98 \\
Friends & 00 & 2 \\
Other way & \multicolumn{3}{c}{ (Multiple response) }
\end{tabular}

$98 \%$ of local visitors and foreign visitors were informed about the Pigeon Island through friends and 78\% of local visitors and $96 \%$ of foreign visitors obtained information in web sites.

Travel history of the visitors on the Pigeon Island

Among the sampled population, none of the foreign visitors visited the Pigeon Island before their first visit. But $34 \%$ of local visitors had an experience of previous visits to the Pigeon Island.

Table 6: Level of participation of the visitors for different activities in previous visits

\section{Activities} Level of participation (\%)

\begin{tabular}{ll}
\hline Boating & 34 \\
Swimming & 32 \\
Scenic visit & 32 \\
Diving visit & 18 \\
Whale watching & 12 \\
Sun bath & 14 \\
\hline (Multiple response)
\end{tabular}

$17 \%$ of the visitors from the sample mentioned that they have participated in boating in the Pigeon Island before this visit. $16 \%$ of them have participated in both swimming and scenic visit. $9 \%$ of the visitors have participated for diving visit. $6 \%$ of them have participated for whale watching and $7 \%$ of them have participated for sun bathing before.

Purpose of the visits to the Pigeon Island

Almost all the visitors used the Pigeon Island for enjoying their vacation.

Table 7: Single or Group visitors

\begin{tabular}{|c|c|c|c|c|}
\hline \multirow{3}{*}{ 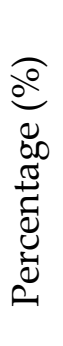 } & \multicolumn{2}{|l|}{$\begin{array}{l}\text { Local } \\
\text { visitors }\end{array}$} & \multicolumn{2}{|c|}{$\begin{array}{l}\text { Foreign } \\
\text { visitors }\end{array}$} \\
\hline & $\frac{\overrightarrow{0}}{\stackrel{0}{0}} \cdot \frac{\vec{n}}{5}$ & 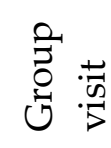 & 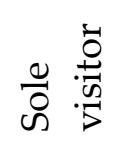 & 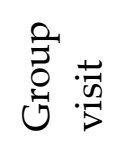 \\
\hline & 2 & 98 & 4 & 96 \\
\hline
\end{tabular}

$98 \%$ of the local visitors visited the Pigeon Island as a group and the rest as a sole visitor. $96 \%$ of the foreign visitors visited the Pigeon Island as a group. $56 \%$ of the visitors had the group size of 2-5. 


\section{Original Article}

Table 8: Level of participation in the activities in Pigeon Island

\begin{tabular}{llllllll}
\hline Activity & & Boating & Swimming & $\begin{array}{l}\text { Scenic } \\
\text { visit }\end{array}$ & $\begin{array}{l}\text { Diving } \\
\text { visit }\end{array}$ & $\begin{array}{l}\text { Whale } \\
\text { watching }\end{array}$ & $\begin{array}{l}\text { Sun } \\
\text { bath }\end{array}$ \\
\hline & $\begin{array}{l}\text { Local } \\
\text { visitors }\end{array}$ & 100 & 98 & 100 & 98 & 44 & 8 \\
& $\begin{array}{l}\text { Foreign } \\
\text { visitors }\end{array}$ & & 90 & 100 & 100 & 100 & 100 \\
$\begin{array}{l}\text { Percentage } \\
(\%)\end{array}$ & & & & & & & \\
\hline
\end{tabular}

Almost all the local visitors came to the Pigeon Island participated in boating and scenic visit. $98 \%$ of them participated in swimming and diving visit. However, almost all the foreign visitors participated in Scenic visit, diving visit, whale watching and
Sunbath. This indicated that the all most all visitors in the temperate countries were interested in doing all the activities in Pigeon Island. Local visitors who participated in whale watching were lower than $50 \%$.

Table 9: Ranking of the preferred activities in the Pigeon Island visit

\begin{tabular}{lllllll}
\hline Activity & Boating & Swimming & $\begin{array}{l}\text { Scenic } \\
\text { visit }\end{array}$ & $\begin{array}{l}\text { Diving } \\
\text { visit }\end{array}$ & $\begin{array}{l}\text { Whale } \\
\text { watching }\end{array}$ & $\begin{array}{l}\text { Sun } \\
\text { bath }\end{array}$ \\
\hline $\begin{array}{l}\text { Percentage of local } \\
\text { visitors who ranked }\end{array}$ & 10 & 6 & 74 & 2 & 2 \\
different activities as & & & & & \\
most preferred \% & & & & & \\
$\begin{array}{l}\text { Percentage of } 54 \\
\text { foreign visitors who } \\
\text { ranked different } \\
\text { activities as most } \\
\text { preferred \% }\end{array}$ & 38 & 2 & 98 & 14 & 2 \\
(Multiple responses) & & & & & \\
\hline
\end{tabular}

According to results, the use of Pigeon Island for diving purpose was ranked by $74 \%$ of local visitors as the most preferred activity and $98 \%$ of the foreign visitors preferred the same activity very much when compared to others.

\section{Most preferred month for the visit}

Table 10: Most preferred month for the visit

\begin{tabular}{|c|c|c|c|c|}
\hline \multirow[t]{2}{*}{ Month } & \multicolumn{2}{|c|}{$\begin{array}{l}\text { Most } \\
\text { preferable } \\
\text { month }\end{array}$} & \multicolumn{2}{|c|}{$\begin{array}{l}\text { Most non- } \\
\text { preferable } \\
\text { month }\end{array}$} \\
\hline & 苞 & . & 竎 & 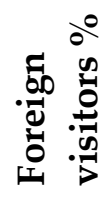 \\
\hline January & & & 66 & 80 \\
\hline
\end{tabular}




\section{Original Article}

\begin{tabular}{lll}
\hline February & 14 & 14 \\
March & 4 & \\
April & 20 & \\
May & 22 & 48 \\
June & & 2 \\
July & & \\
August & 16 & \\
September & 22 & 36 \\
October & & \\
\hline
\end{tabular}

\begin{tabular}{lll}
\hline November & 8 & \\
December & 26 & 20 \\
\hline
\end{tabular}

Majority of the visitors like to visit the Pigeon Island in the months of May and September and they don't like to visit Pigeon Island in the months of January, November and December.

\section{Costs encountered in the Pigeon Island visit}

Table 11: Average costs for the activities done in the Pigeon Island

\begin{tabular}{lllll}
\hline Activity & \multicolumn{2}{l}{ Foreign visitors } & Local visitors \\
\cline { 2 - 5 } & $\begin{array}{l}\text { Mean } \\
\text { per hour (Rs) }\end{array}$ & $\begin{array}{l}\text { Standard } \\
\text { deviation }\end{array}$ & Mean cost per hour (Rs) & Standard deviation \\
\cline { 2 - 5 } Boating & 1300.00 & 247.00 & 717.00 & 23.93 \\
Swimming & 0.00 & 0.00 & 0.00 & 0.00 \\
Scenic visit & 0.00 & 0.00 & 0.00 & 0.00 \\
Diving visit & 3470.00 & 255.00 & 1145.83 & 290.97 \\
Whale & 1493.00 & 106.00 & 889.89 & 144.34 \\
watching & & & & 0.00 \\
Sun bath & 0.00 & 0.00 & 0.00 & \\
\hline
\end{tabular}

Traditionally, coastal resources are open to everyone (Costanza et al., 1999). Many countries' coastal waters and their resources are considered 'commons', i.e. they are not owned by any person or agency but are common property available equally to all citizens (Clark, 1998). Their common property nature makes it impossible to exclude those who do not pay for enjoying or using them. But in contrast to this, in Pigeon Island every single visitor has to pay for their visit and certain activities. Average cost for boating was Rs.1300 per hour for foreign visitors, average cost for diving wasRs.3470 per person per hour which were nearly twice the value that of local visitors.

Table 12: Willingness to pay for the activities done in the Pigeon Island

\begin{tabular}{lllll}
\hline Activity & Foreign visitors & \multicolumn{3}{l}{ Local visitors } \\
\cline { 2 - 5 } & Mean & Standard & Mean & Standard \\
willingness to deviation & willingness to deviation \\
pay for the & pay for the \\
activity(Rs) & & activity(Rs) & \\
\hline
\end{tabular}




\section{Original Article}

\begin{tabular}{lllll}
\hline Boating & 1454 & 302.51 & 784 & 95.53 \\
Swimming & 375 & 144.72 & 70.60 & 26.37 \\
Scenic visit & 365 & 144.36 & 69.60 & 24.15 \\
Diving visit & 3670 & 435.77 & 1240 & 252.33 \\
Whale & 1510 & 123.30 & 919 & 230.54 \\
watching & & & & \\
Sun bath & 365 & 144.36 & 64.60 & 24.59 \\
\hline
\end{tabular}

Willingness-to-pay is the maximum amount an individual is willing to give off in exchange on changes in the provision of resources (Anderson, 2004). According to the result, foreign visitors' mean willingness to pay for diving was Rs.3670 and for local visitors it was Rs.1240. It was interesting to note that although currently there were no any charges claimed for some activities, but visitors were willing to pay those activities such as swimming, scenic visit and sunbath. This clearly shows that pricing system should be restructured for different activities.

\section{Entrance fee and willingness to pay for the entrance fees}

Entrance fee for the foreign visitors was Rs.1000 and for the local visitors was Rs.500. Average willingness to pay of the foreign visitors for entrance fee wasRs.1560 and the average willingness to pay of the local visitors for the entrance fee was Rs.644 which indicates visitors were willing to pay an increased entrance fee toward the improvement of facilities.

Table 13: Entrance fee and Willingness to pay for the Entrance fees to Pigeon Island

\begin{tabular}{ccccc}
\hline & \multicolumn{2}{c}{ Foreign visitors } & \multicolumn{2}{c}{ Local visitors } \\
\cline { 2 - 5 } & Mean & Standard deviation & Mean & $\begin{array}{c}\text { Standard } \\
\text { deviation }\end{array}$ \\
\hline Entrance fee (Rs) & 1000 & 0.00 & 500 & 0.00 \\
$\begin{array}{c}\text { Willingness to } \\
\text { pay for the } \\
\text { entrance fee (Rs) }\end{array}$ & 1560 & 239.89 & 644 & 88.43 \\
\hline
\end{tabular}

Table 14: Total cost for the Pigeon Island visit

\begin{tabular}{|c|c|c|c|c|}
\hline & \multicolumn{2}{|c|}{ Foreign visitors } & \multicolumn{2}{|c|}{ Local visitors } \\
\hline & Mean & $\begin{array}{l}\text { Standard } \\
\text { deviation }\end{array}$ & Mean & $\begin{array}{l}\text { Standard } \\
\text { deviation }\end{array}$ \\
\hline $\begin{array}{l}\text { Total cost (including } \\
\text { transportation, } \\
\text { lodging, meals) Rs }\end{array}$ & 16272 & 924.23 & 5320.60 & 310.04 \\
\hline
\end{tabular}




\section{Original Article}

Foreign visitors who visited the Pigeon Island had spent averagely Rs.16272 as onsite expenditures in Pigeon Island visit.

\section{Regression analysis}

Table below shows results of multiple regression analysis for the total willingness to pay of the visitors. The $\mathrm{R}^{2}$ was 0.762 which implied that about $76.2 \%$ of the variation in the total willingness to pay was explained by different regressors. Total willingness to pay of the visitors was significantly affected by age of the respondent, hours of spending, number of the group members and expenses for meals.

Therefore, estimated model can be written as follows,

Total willingness to pay $=-1339.60+$ 50.25Age +743.70 gender -376.15 marital status +3751.38 hours of spending - 49.97 number of group members +0.11 expenses for meals.

The results revealed that an increase in hours of spending on the Pigeon Island visit by one unit the total willingness to pay of the visitors will be increased by Rs. 3751.38 ( $p<0.01)$.

Table 15: Results of Multiple Regression Analysis of Total willingness to pay

\begin{tabular}{lrr}
\hline Variable & Unstandardized Coefficients \\
\hline & B & Std. Error \\
(Constant) & -1339.60 & 1079.98 \\
Age (Years) & $50.25^{* *}$ & 18.99 \\
Marital status of the respondent & & \\
(Single/married) & $376.15^{* *}$ & 365.58 \\
Gender of the respondent (Male/ female) & 743.71 & 311.06 \\
Hours of spending (Hours) & $3751.38^{* *}$ & 356.47 \\
Number of group members (Numbers) & $-49.98^{* *}$ & 18.64 \\
Expenses for the meals (Rs) & $0.12^{* *}$ & 0.07 \\
\hline
\end{tabular}

Dependent variable: Willingness to pay of the visitors (Rs)

*Significant at $10 \%$ level

**Significant at $5 \%$ level

***Significant at $1 \%$ level

\section{T-test result}

for their total willingness to pay on

Result showed that there was a Pigeon Island visit.

significant difference $(p<0.01)$ between the Foreign visitors and local visitors 


\section{Original Article}

ISSN: 2279-3933

Table 16: Independent samples T-test between foreign visitors and local visitors for total willingness to pay on Pigeon Island visit

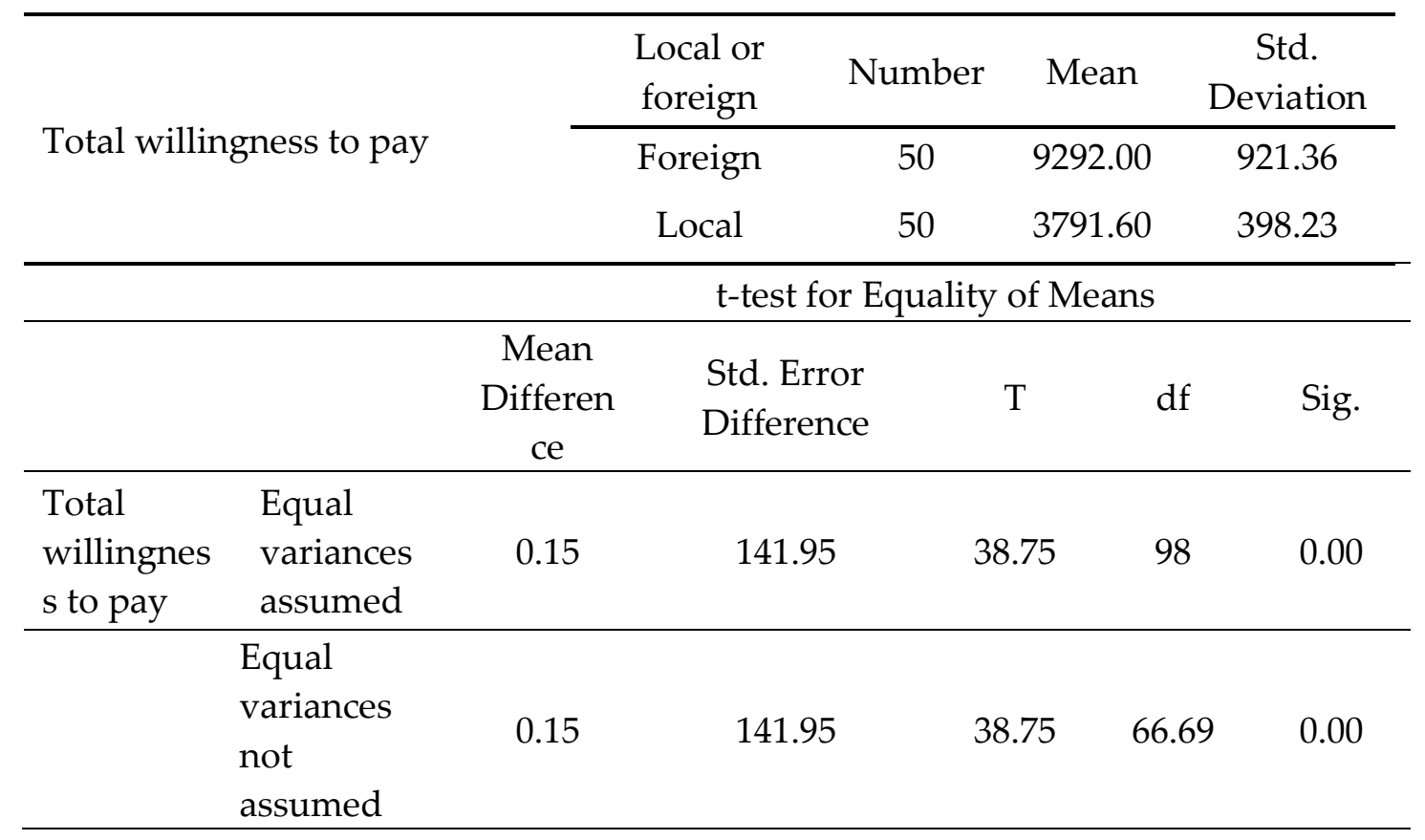

Table 17: Independent samples T-test between foreign visitors and local visitors for total hours of spending on the Pigeon Island visit

\begin{tabular}{|c|c|c|c|c|c|c|}
\hline \multirow{2}{*}{\multicolumn{2}{|c|}{$\begin{array}{l}\text { Total hours of spending on } \\
\text { the Pigeon Island visit }\end{array}$}} & \multirow{3}{*}{$\begin{array}{c}\begin{array}{c}\text { Local or } \\
\text { foreign }\end{array} \\
\text { Foreign } \\
\text { Local }\end{array}$} & \multirow{3}{*}{$\begin{array}{c}\text { Number } \\
50 \\
50\end{array}$} & \multirow{3}{*}{$\begin{array}{c}\text { Mean } \\
2.02 \\
1.12\end{array}$} & \multicolumn{2}{|c|}{$\begin{array}{c}\text { Std. } \\
\text { Deviation }\end{array}$} \\
\hline & & & & & \multirow{2}{*}{\multicolumn{2}{|c|}{$\begin{array}{l}0.247 \\
0.328\end{array}$}} \\
\hline & & & & & & \\
\hline & & \multicolumn{5}{|c|}{ t-test for Equality of Means } \\
\hline & & $\begin{array}{c}\text { Mean } \\
\text { Difference }\end{array}$ & $\begin{array}{l}\text { Std. Error } \\
\text { Difference }\end{array}$ & $\mathrm{t}$ & df & Sig. \\
\hline \multirow{2}{*}{$\begin{array}{l}\text { Total hours } \\
\text { of spending } \\
\text { on the } \\
\text { Pigeon } \\
\text { Island visit }\end{array}$} & $\begin{array}{l}\text { Equal } \\
\text { variances } \\
\text { assumed }\end{array}$ & 0.90 & .058 & 15.50 & 98 & 0.00 \\
\hline & $\begin{array}{l}\text { Equal } \\
\text { variances not } \\
\text { assumed }\end{array}$ & 0.90 & .058 & 15.50 & 90.95 & 0.00 \\
\hline
\end{tabular}

Result revealed that there was a significant difference $(\mathrm{p}<0.01)$ between the Foreign visitors and local visitors in hours of spending on Pigeon Island visit. 


\section{Original Article}

ISSN: 2279-3933

Table 18: Independent samples T-test between foreign visitors and local visitors for Willingness to pay for entrance fee

\begin{tabular}{|c|c|c|c|c|c|c|}
\hline & & $\begin{array}{l}\text { Local or } \\
\text { foreign }\end{array}$ & Number & Mean & \multicolumn{2}{|c|}{$\begin{array}{c}\text { Std. } \\
\text { Deviation }\end{array}$} \\
\hline \multirow{4}{*}{\multicolumn{2}{|c|}{$\begin{array}{l}\text { Willingness to pay for } \\
\text { entrance fee }\end{array}$}} & Foreign & 50 & 1560.00 & & .89 \\
\hline & & Local & 50 & 644.00 & & 43 \\
\hline & & \multicolumn{5}{|c|}{ t-test for Equality of Means } \\
\hline & & $\begin{array}{c}\text { Mean } \\
\text { Difference }\end{array}$ & $\begin{array}{l}\text { Std. Error } \\
\text { Difference }\end{array}$ & $\mathrm{t}$ & df & Sig. \\
\hline \multirow{2}{*}{$\begin{array}{l}\text { Willingness } \\
\text { to pay for } \\
\text { entrance fee }\end{array}$} & $\begin{array}{l}\text { Equal } \\
\text { variances } \\
\text { assumed } \\
\end{array}$ & 916.00 & 36.16 & 25.33 & 98 & 0.00 \\
\hline & $\begin{array}{l}\text { Equal } \\
\text { variances not } \\
\text { assumed }\end{array}$ & 916.00 & 36.16 & 25.33 & 62.07 & 0.00 \\
\hline
\end{tabular}

A significant difference $(p<0.01)$ was observed between the foreign visitors and local visitors for willingness to pay their entrance fee and foreign visitors were willing to pay Rs. 916.00 higher than the local visitors.

Table 19: Independent samples T-test between foreign visitors and local visitors for Cost of boating per hour

\begin{tabular}{|c|c|c|c|c|c|c|}
\hline & & $\begin{array}{l}\text { Local or } \\
\text { foreign }\end{array}$ & Number & Mean & \multicolumn{2}{|c|}{$\begin{array}{c}\text { Std. } \\
\text { Deviation }\end{array}$} \\
\hline \multirow{2}{*}{\multicolumn{2}{|c|}{ Cost for boating per hour }} & Foreign & 50 & 1300.00 & \multicolumn{2}{|r|}{247.44} \\
\hline & & Local & 50 & 717.00 & \multicolumn{2}{|r|}{23.93} \\
\hline & & \multicolumn{5}{|c|}{ t-test for Equality of Means } \\
\hline & & $\begin{array}{c}\text { Mean } \\
\text { Difference }\end{array}$ & $\begin{array}{l}\text { Std. Error } \\
\text { Difference }\end{array}$ & $\mathrm{T}$ & $\mathrm{df}$ & Sig. \\
\hline \multirow[t]{2}{*}{$\begin{array}{l}\text { Cost for } \\
\text { boating per } \\
\text { hour }\end{array}$} & $\begin{array}{l}\text { Equal } \\
\text { variances } \\
\text { assumed }\end{array}$ & 583.00 & 36.16 & 16.58 & 98 & 0.00 \\
\hline & $\begin{array}{l}\text { Equal } \\
\text { variances not } \\
\text { assumed }\end{array}$ & 583.00 & 36.16 & 16.58 & 49.92 & 0.00 \\
\hline
\end{tabular}




\section{Original Article}

Results showed that a significant difference $(p<0.01)$ between the Foreign visitors and local visitors for cost for boating per hour and foreign visitors pay Rs. 583.00 than local visitors for boating.

Table 20: Independent samples T-test between foreign visitors and local visitors for Cost for diving visit

\begin{tabular}{|c|c|c|c|c|c|c|}
\hline & & $\begin{array}{l}\text { Local or } \\
\text { foreign }\end{array}$ & Number & Mean & \multicolumn{2}{|c|}{$\begin{array}{c}\text { Std. } \\
\text { Deviation }\end{array}$} \\
\hline \multirow{4}{*}{\multicolumn{2}{|c|}{ Cost for diving visit }} & Foreig & 50 & 3470.00 & & 5.75 \\
\hline & & Local & 48 & 1145.83 & & 0.97 \\
\hline & & \multicolumn{5}{|c|}{ t-test for Equality of Means } \\
\hline & & $\begin{array}{c}\text { Mean } \\
\text { Difference }\end{array}$ & $\begin{array}{l}\text { Std. Error } \\
\text { Difference }\end{array}$ & $\mathrm{t}$ & $\mathrm{df}$ & Sig. \\
\hline \multirow[t]{2}{*}{$\begin{array}{l}\text { Cost for } \\
\text { diving visit }\end{array}$} & $\begin{array}{l}\text { Equal } \\
\text { variances } \\
\text { assumed } \\
\end{array}$ & 2324.17 & 55.28 & 42.04 & 96 & 0.00 \\
\hline & $\begin{array}{l}\text { Equal } \\
\text { variances not } \\
\text { assumed }\end{array}$ & 2324.17 & 55.43 & 41.93 & 93.33 & 0.00 \\
\hline
\end{tabular}

Table 21: Chi square analysis between total willingness to pay of the local visitors and selected independent variables

\begin{tabular}{lllll}
\hline Independent variable & $\boldsymbol{X}^{\mathbf{2}}$ & $\mathbf{d f}$ & P value & Decision \\
\hline $\begin{array}{l}\text { Education level of the } \\
\text { respondent }\end{array}$ & 76.76 & 46 & 0.00 & Highly significant \\
$\begin{array}{l}\text { Cost for boating in the } \\
\text { Pigeon Island }\end{array}$ & 36.53 & 23 & 0.04 & Significant \\
Marital status & 71.22 & 46 & 0.01 & High significant \\
\hline
\end{tabular}

There was a high significant level of the respondent $\left(X^{2}=76.756, \mathrm{p}<\right.$ association observed between the total $0.01)$. willingness to pay and the education

Table 22: Chi square analysis between total willingness to pay of the foreign visitors and selected independent variables

\begin{tabular}{lllll}
\hline Independent variable & $\boldsymbol{X}^{\mathbf{2}}$ & $\mathbf{d f}$ & $\mathbf{P}$ value & Decision \\
\hline $\begin{array}{l}\text { Education level of the } \\
\text { respondent }\end{array}$ & 49.62 & 34 & 0.04 & Significant \\
& & & & \\
\hline
\end{tabular}


Duration of staying

Cost for diving in the

Pigeon Island

Cost for whale watching

\subsection{1}

48.56

102.08

\section{4}

\section{4}

68
0.03

0.05

0.005
Significant

Significant

Highly significant
There was a highly significant association observed between the total willingness to pay and the cost for whale watching in the Pigeon Island $\left(X^{2}=102.083, \mathrm{p}<0.01\right)$.

\section{CONCLUSIONS AND RECOMMENDATIONS}

This study employed the Contingent valuation Method to determine the relationship among travel and socio demographic information and activities in the Pigeon Island. The objective of this research was to explore the recreational value of the Pigeon Island. Descriptive statistics was done for questionnaires to explore the socio economic status of the visitors. T test and chi square test were also employed. Multiple regression analysis was done to explore the factors affecting travels of visitors on their total willingness to pay. The result indicated $50 \%$ of the local visitors in the sample population were receiving a monthly income within the range of Rs.30000-40000. 38\% of the foreigners were educated up to Master's or equivalent level and 20\% up to Doctoral or equivalent level. The results also revealed that, the use of Pigeon Island for diving was ranked by $74 \%$ of local visitors as the most preferred activity. Foreign visitors' mean willingness to pay for boating was Rs.1454, for swimming was
Rs.375, for scenic visit was Rs. 365, for diving visit was Rs.3670, for whale watching was Rs.1510 and for sun bath was Rs.365. Mean willingness to pay of local visitors' for boating was Rs.784, for swimming was Rs.70.60, for scenic visit was Rs.69.60, for diving visit was Rs.1240, for whale watching was Rs.919.00 and for sun bath was Rs.64.60. Average willingness to pay of the foreign visitors for entrance fee was Rs.1560 and the average willingness to pay of the local visitors for the entrance fee was Rs 644.00.

Results of the $\mathrm{T}$ test showed that significant difference between foreign visitors and local visitors in total willingness to pay on the Pigeon Island visit, hours of spending on the Pigeon Island, willingness to pay for the entrance fee, cost for boating, cost for diving visit and cost for whale watching. Chi square analysis showed that there was a high significant association between the total willingness to pay of the local visitors and the education level of the respondent. Multiple regression analysis showed that total willingness to pay of the visitors was significantly affected by age of the respondent, hours of spending, number of the group members and expenses for meals. The analysis showed that the recreational benefits received by the visitors are much higher than the 
amount they pay at present. The current entrance fees do not capture the economic value of the Pigeon Island. Therefore, it is recommended to increase the entrance fees and fees for different activities.

It was found that a suitable management plan should be formulated in maintaining quality of Pigeon Island service in association with the preference of the community that can result in increased revenue generation.

\section{References}

Bandara, H. and Ratnayake, I.(2015). Coastal Land Uses for Tourism in Sri Lanka: Conflicts and Planning Efforts. Sabaragamuwa University Journal, 14(1), 41-57

Clark, J. (1998). Coastal Seas: The Conservation Challenge.Oxford, UK: Blackwell Science Costanza, R.,D'Arge, R., De Groot, R., Farber, S., Grasso, M., Hannon, B., Limburg, K., Naeem, S., O'Neill, R., Paruelo, J., Raskin, R., Sutton, P., and van den Belt, M.(1997).The value of the world's ecosystem services and natural capital. Nature. 387 (6630), 253-260.

Davis, R. K. (1963). Recreation planning as an economic problem. Natural Resources Journal. 3(1), 239-249.

Dixon, J.A. and Hufschmidt, M.(1986). Economic Valuation Techniques for the Environment. London, UK: The Johns Hopkins University Press.

Francisco, H.A. and Glover, D,.(1999). Economy and Environment: Case Studies in Vietnam. Singapore: International Development Research Centre.

IUCN Sri Lanka and the Central Environmental Authority. 2006. National wetland directory of Sri Lanka. Colombo, Sri Lanka: IUCN Sri Lanka and the Central Environmental Authority.
IUCN Sri Lanka. 2002. Conservation of coral reefs around Pigeon Island, Trincomalee. Colombo, Sri Lanka: IUCN Sri Lanka and the Central Environmental Authority.

Jean M. R. (2002). Integrated coastal zone management (ICZM) in Haiti: Opportunities and limitations. Retrieved from

https://www.elibrary.ru/item.asp?id=528 3997

Jin J., Ran S. and Zhang,L.(2002). A study on the cost of coastal zone resources (in Chinese with English abstract).Marine Environment Science. 21(1), 63-67.

Jude, A, Jayakody D.M.M. S, PereraK.S.M, PathmanathanN.G.,Kurubaran $\mathrm{T}$ and Subramaniam T.(2011). Sri Lanka Tourism Industry and a land like no otherRetrieved from https://landlikenoother.lk/

Cleaver, K. (2007).Global Environmental Facility.Participatory Coastal Zone Restoration and Sustainable Management in the Eastern Province of Post-Tsunami Sri Lanka Project. Retrieved from https://www.thegef.org/project/participa tory-coastal-zone-restoration-andsustainable-management-easternprovince-post

Liston-Heyes, C. and Heyes, A. (1999). Recreational Benefits from the Dartmoor National Park.Journal of Environmental Management. 55 (1), 69-80.

Perera, N.M. and Kotagama, S.W.(2016). Coexistence of Coral Reef Conservation and Tourism at Pigeon Island National Park. Journal of Tropical Forestry and Environment. 6(1).20-29.

Reinecke, (2007). Pigeon Island National Park. Available at www.amazinglanka.com.

United Nations Environment Programme, Annual Evaluation report, (2005).

Walsh, R.G. (1986). Recreation Economic Decisions: Comparing Benefits and Costs, State College, PA: Venture.

Walters, J.S., Maragos. J, Siar.S and White.A.T,.(1998).Participatory Coastal Resource Assessment: A Handbook for 
Community Workers and Coastal Resource

Managers. Cebu City, Philippines:

Coastal Resource Management Project of the Silliman University. 